\title{
AZ OSTORCSAPÁS-EFFEKTUS HATÁSA AZ ELLÁTÁSILÁNC-KOORDINÁCIÓRA
}

\section{IMPACTS OF BULLWHIP-EFFECT IN THE CASE OF SUPPLY CHAIN COORDINATION}

\author{
Faludi Tamás ${ }^{1}$ \\ ${ }^{1}$ Vezetéstudományi Intézet, Gazdaságtudományi Kar, Miskolci Egyetem, Magyarország
}

\begin{abstract}
Kulcsszavak:
\end{abstract}
ellátásilánc-menedzsment, ellátásilánc-koordináció, ostorcsapás-effektus

Keywords:

supply chain management, supply chain coordination, bullwhip effect

\begin{abstract}
Összefoglalás
A cikk az ellátásilánc-menedzsment egyik meghatározó problematikájával, az ostorcsapáseffektussal foglalkozik. Ez a jelenség nagyban befolyásolja az ellátásilánc-koordinációt is, mely manapság nagyon fontos szegmense az ellátásilánc-menedzsmentnek és az ellátási láncok sikerességének egyik központi eleme. A cikk továbbá bemutatja az ostorcsapás-effektus kialakulásának okait, illetve javaslatot tesz az ostorcsapás-effektus negatív hatásainak csökkentésére.

\section{Abstract}

The paper deals with one of the most important problem of supply chain management - the bullwhip effect. This phenomenon influences the coordination of supply chain. The issue of coordination is the key element in the success of supply chains. The aim of paper is to introduce the causes of the bullwhip effect, to present its impacts on the coordination of supply chains. It makes suggestions to decrease the negative impacts of bullwhip effect.
\end{abstract}

\section{Bevezetés}

Az ellátásilánc-menedzsment napjaink egyik egyre nagyobb ütemben fejlődő szakterülete. Jelentősége az ezredforduló idején növekedett meg. Eleinte, az 1980-as és 1990-es években még a logisztikától függő vagy azzal egyenértékű területként tartották számon. Azonban a különböző vizsgálatok és kutatások rávilágítottak arra, hogy az ellátásilánc-menedzsment igen is képes önálló szakterületként is létezni, sőt a 2000-es évekre, miután a gyakorlati hasznosságának definiálása megtörtént, egy sokkal összetettebb szakterületként azonosították, mint a logisztikát [6]. Ekkora nem a logisztika egyik támogató, segítő folyamata volt az ellátásilánc-menedzsment, hanem egy teljesen önálló területté nőtte ki magát. Ez részben köszönhető volt annak, hogy többek között a globalizáció hatására partnerszámukban megnövekedett ellátási láncok irányítása, vezetése, szervezése egyre nagyobb kihívásnak tưnt. Ezt a problémát kell az ellátásilánc-menedzsmentnek elsősorban kezelnie, megoldania.

Manapság az ellátási láncok annyira kiterjedt kapcsolatrendszerrel rendelkeznek, hogy nagyon nehéz optimálisan és hatékonyan múködtetni őket. Az ellátási lánc koordinációjának a kérdése így nagyon fontossá vált, hiszen ezzel érhető el, hogy az ellátási lánc teljes egysége és a láncon belüli tagok is eredményesen tudjanak müködni.

A koordinációt befolyásoló egyik nagyon fontos jelenség az ostorcsapás-effektus, melynek csökkentésével pozitív irányba befolyásolhatjuk a koordinációt. Jelen cikk az ostorcsapás-effektust

${ }^{1}$ E-mail cím: szvft@uni-miskolc.hu 
hivatott bemutatni, illetve rávilágít arra, hogy miért fontos foglalkozni ezzel a jelenséggel a koordinációs problémák megoldásának tükrében.

\section{Az ellátásilánc-koordináció}

A koordináció alapvetően a tevékenységek összehangolását jelenti. A '90-es években született definíció alapján a koordináció azokat a függőségeket kezeli, melyek a vállalaton belül realizált tevékenységek között jönnek létre [10]. Az ellátási lánc esetében nem csak a vállalaton belül alakulhatnak ki függőségi viszonyok, hanem a vállalatok között is. Hiszen az ellátási lánc lényege, hogy a láncon belül müködő vállalatok értékteremtő folyamatai összekapcsolódnak [4]. A koordináció fogalma tulajdonképpen ezzel a gondolattal módosult az évek során. Vagyis már nem csak a vállalaton belülre kellett koncentrálni, hanem a vállalaton kívüli, társaságok közötti tevékenységek összehangolásával is foglalkozni kellett a menedzsmenteknek.

Az ellátási láncon belül sokféle szervezetnek kell együttmüködnie, kezdve a beszállítóktól, a disztribútorokon, nagykereskedőkön át, egészen a kiskereskedőkig. Ez azt jelenti, hogy más és más profillal rendelkező cégeknek kell kooperálniuk. Dobák és Antal [7] erre hívta fel a figyelmet; minél jobban különböznek az együttmúködő vállalatok, annál nagyobb szükség van a tudatosan tervezett koordinációra. Itt nem az egyéni célokat kell elsősorban megvalósítani, hanem a partnereknek egy közös célt kell definiálniuk, mely az ellátási lánc célját fogja jelenteni.

$\mathrm{Az}$ ellátásilánc-koordináció feltétele, hogy minden lánctag adaptálja az egész lánc tevékenységének optimális múködését elősegítő folyamatokat [16]. Ehhez szükséges az is továbbá, hogy az egész láncot egyben, egy nagy folyamatként is definiálni tudják, és képesek legyenek átlátni az egész lánc, és egyenként a lánctagok tevékenységeit is. Az ellátási lánc koncepciójának elsajátítása segít a vállalatok menedzsmenti szintjeinek megérteni az ellátásilánc-menedzsment, azon belül is a koordináció fontosságát. Ezenkívül elérhetővé válnak olyan információk a lánccal kapcsolatban, melyek átláthatóbbá teszik a lánctagok értékteremtő folyamatait, ezáltal is segítve az eredményes müködést. Amennyiben a koncepciót sikeresen adaptálták, meghatározhatók a közös célok, melyek elérését fogja segíteni az ellátásilánc-koordináció a különböző koordinációs mechanizmusok segítségével [9].

\section{Az ostorcsapás-effektus}

Koordináció hiányában csökkenhet az ellátási lánc hatékonyságának és eredményességének szintje. Szélsőséges dominancia alakulhat ki, kiegyensúlyozatlan erőviszonyok jöhetnek létre, az egyéni érdekek jobban előtérbe kerülhetnek, mint a lánc közös céljai és így decentralizált működés felé sodródhat az egész ellátási lánc. Kommunikációs problémák adódhatnak, mely elsődlegesen az információáramlásra lesznek negatív hatással. Ez pedig különböző veszteségek forrása lehet, mint például az igények pontatlan ismeretéből származó nem megfelelő minőségű és mennyiségü áru rendelése, szállítása, raktározása, készletezése [1]. A racionálisan viselkedő vállalatok az információ hiánya miatt inkább egy bizonyos mennyiségü készletet halmoznak fel annak érdekében, hogy bármilyen felmerülő igényt ki tudjanak elégíteni. Ezzel viszont többletköltségek keletkeznek, melyek szintén rontják az adott vállalat, és ezáltal annak az ellátási láncnak is a hatékony múködését, melynek része ez a társaság. Ez visszavezethető arra, hogy a lánctagok csak a láncban közvetlenül mellettük lévő tagra összpontosítanak, ami azt jelenti, hogy nem sikerült megfelelően elsajátítani az ellátásilánc-koncepciót. A legnagyobb problémát az okozza, ha az egész láncot éri ez a hatás. Ekkor beszélünk ostorcsapás-effektusról.

A végső fogyasztótól távolodva, vagyis az ellátási láncon visszafelé haladva tapasztalható rendelési mennyiségek ingadozását jelenti az ostorcsapás-effektus. Ez feltételezi a keresleti előrejelzések pontatlanságát, melyet készletek felhalmozásával próbálnak kivédeni a lánctagok [12].

Az 1. ábra megmutatja, hogyan alakul egy alap ellátási lánc esetében az ostorcsapás-effektus, ha a fogyasztóhoz a legközelebb álló kiskereskedő rendelési ingadozását és a fogyasztóhoz legtávolabb álló termelő rendelési ingadozását viszonyítjuk a realizált vásárlói igényekhez. 


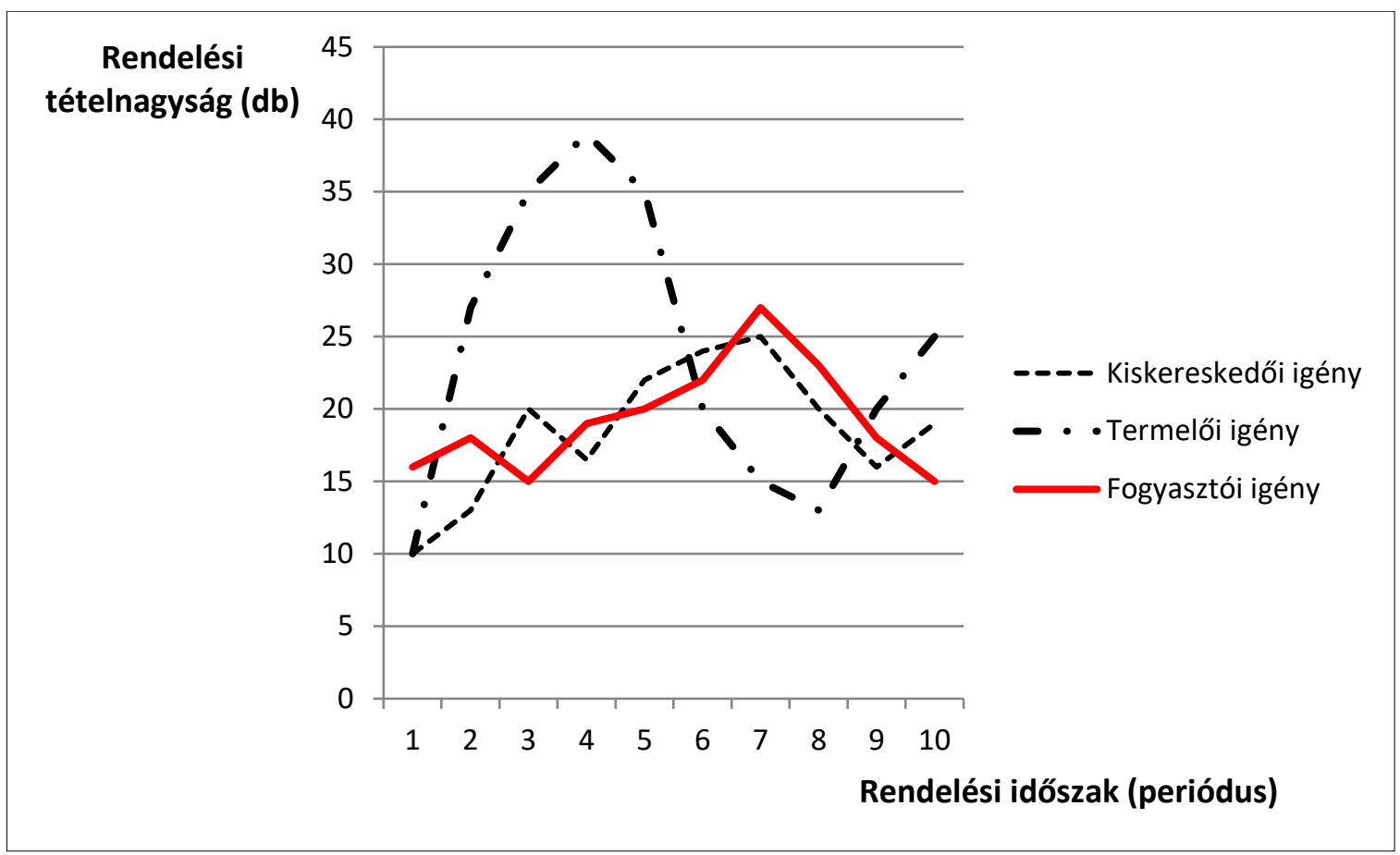

1. ábra. Ostorcsapás-effektus bemutatása a kiskereskedő és a termelő vállalat esetében (forrás: saját szerkesztés [2] alapján)

Az 1. ábrán látható, hogy míg a kiskereskedő görbéje viszonylag kisebb mértékű kilengést mutat, addig a termelőnek a keresleti görbéje határozottan eltér a kiskereskedőétôl és egyúttal a fogyasztói igényektől is nagyon távol marad. A különbség elsődleges okozója az elégtelen információ. A kiskereskedő helyezkedik el a legközelebb a fogyasztóhoz, így viszonylag pontos információkkal rendelkezik a piaci igényekről, ehhez viszonyítva tudja beállítani a számára megfelelő rendelési tételnagyságot. A termelő messze helyezkedik el a piactól, a kiskereskedő és közte még egy egyszerúbb ellátási lánc esetén legalább egy vagy kettő másik vállalat is elhelyezkedik, ami azt jelenti, hogy nehezen tudja megállapítani a valós piaci igényeket nem megfelelő információáramlás esetén. Ezért térhetnek el ilyen nagymértékben a rendelési nagyságok. A nem valós igényeknek megfelelően rendelt áruból pedig többletkészlet fog keletkezni, mely növeli a vállalat költségeit, ennek megfelelően pedig csökkenti az eredményes müködését.

$\mathrm{Az}$ 1. ábra elemzésével és az ostorcsapás-effektus fogalmának megismerésével az a következtetés levonható, hogy minél távolabb van egy lánctag a végső fogyasztótól, annál nagyobb kilengést mutatnak a rendelési tételnagyságra vonatkozó adatok.

Az ostorcsapás-effektus kialakulásának okait egyes kutatók szerint két nagy csoportra bonthatjuk. Az egyik csoport a tagok viselkedéséből eredő okok, mely - a már említett - racionális viselkedést foglalja magába. A másik csoport a lánctagok múködéséből adódó problémák, melyek származhatnak adatbeviteli tévedésekből, szándékosan kreált áringadozásból, vagy a megrendelések csomagolásából eredő hibákból, hiányosságokból [5]. Más megközelítés alapján lehetnek az ostorcsapás-effektus létrejöttének szimplán külső okai, melyek visszavezethetők konkrétan a beszállítói és a vevői oldalra egyaránt, illetve egy adott lánctag belső okai is erősíthetik a jelenséget [14].

Az ellátásilánc-menedzsment egyik legfőbb feladata az ezredforduló után tehát az lett, hogy a lánctagok közötti koordinációt a lehető legeredményesebben végrehajtsa. Ehhez viszont elengedhetetlen, hogy csökkentse a láncokban fellelhető ostorcsapás-effektus hatásait.

\section{Az ostorcsapás-effektus negatív hatásai a koordinációra}

Lényegében a problémát az okozza, hogy a lánctagok nem ismerik pontosan a keresletet. Ez pedig számos negatív hatást indukál.

Az 1. ábrán máris szembesülhetünk az egyik legnagyobb negatívummal, amit az ostorcsapáseffektus okozhat. A valós kereslethez nem alkalmazkodó készletek jönnek létre az egyes lánctagoknál. 
Ha a fogyasztói igény görbéje alatt helyezkednek el az ellátási lánc tagjainak rendelési görbéi, az készlethiányt jelent. Ebben az esetben a felmerült fogyasztói igényeket nem tudja maradéktalanul kielégíteni az adott vállalat. Amennyiben a tagok görbéje jóval a keresleti görbe felett helyezkedik el, az többletkészletként definiálható. Természetesen nem reális elvárás az, hogy a görbék teljes mértékben fedjék és kövessék egymást, hiszen akkor olyan mértékű együttmúködést kellene feltételezni, amit a való életben lehetetlen kivitelezni. A szakemberek és az üzleti életben fellelhető információk alapján a készletek teljes egészében nem szüntethetők meg - hiszen még a Just In Time rendszernek sem sikerül 100\%-osan kiiktatni a készleteket az ellátási láncból. Csupán a készletek mennyisége a kritikus kérdés. A túlzott felhalmozódás magas készlettartási költségeket jelent, mely rontja a vállalat múködését, továbbá a selejtek keletkezésének valószínüségét is növeli, mely szintén veszteségként jelenik meg. A készlethiány pedig a vevőkiszolgálás színvonalát is negatív irányba fogja befolyásolni.

A kereslet ingadozása miatt egyenetlen lesz a lánctagok erőforrás-kihasználása, ezért ebben az esetben akár csökkenhet is annak hatékonysága. Növekvő keresletnél nagyobb az erőforrás-igény, amit nem minden esetben tudnak biztosítani a vállalatok. Ekkor kapacitáshiányról beszélhetünk. Csökkenő keresletnél pedig ezen erőforrások kihasználatlanul maradnak [14]. Mindkét eset költséget jelent és veszteséget termel a lánctagok számára.

Az effektus jelenlétét számszerüsíteni is lehet, így nem csak realizálhatjuk a problémát, hanem annak erőssége is meghatározhatóvá válik. A szakirodalomban található különféle számítási módszer az ostorcsapás-effektus mérésére [5], [15], ám mégis a legelterjedtebb mutatószám, mely az ezzel kapcsolatos számítások alapját is nagyrészt képezi a BWR, vagyis a Bullwhip Ratio. A mutató a relatív szórást alkalmazza az érték kiszámításához. Adott lánctag, adott periódusban leadott rendelési tételének relatív szórása és az adott lánctagot megelőző tag szükségletei relatív szórásának a hányadosa lesz a BWR. Abban az esetben, ha ez az érték nagyobb 1-nél, ostorcsapás-effektus realizálható az adott ellátási láncban [3].

Az ostorcsapás-effektus egy valós probléma, mely sok ellátási láncot sújt már a '90-es évek végétől kezdve. Ez betudható a partnerszámok megnövekedésének, mely még távolabbra helyezte az egyes lánctagokat a valós piaci igények ismeretétől. Mindezek mellett a koordinációra is nagy hatással van, és ezért is vált nagyon fontos területté az ellátásilánc-menedzsmenten belül a láncok koordinációjának a kutatása.

\section{Javaslatok az ostorcsapás-effektus hatásainak csökkentésére}

Az ostorcsapás-effektus megnehezíti a partnerek közötti kooperációt, és voltaképpen a nem megfelelő információáramlás meglétét feltételezi, ami pedig kommunikációs hiányosságokat valószínűsít. Ezek az okok pedig egyértelműen rontják az ellátási láncok koordinációját. Így az elsődleges cél ennek javítása, vagyis az információáramlás hatékonyságának növelése. Ehhez sok gyakorlati eszköz lehet a vállalatok segítségére, mint például a különböző vállalatirányítási rendszerek. Ezek segítségével nyomon követhetik a cégek a saját, és partnerük készletezését, ellenőrizhetik az igényeket, akár valós idejü visszajelzéseket és adatokat gyüjthetnek össze mindezek változásairól.

Érdemes lehet még egy ellátási lánc vezetőt kinevezni a láncon belül. A centralizált elrendezésben múködő ellátási láncok a szakirodalom alapján hatékonyabban múködnek [8]. Egy ilyen lánc esetében nem a saját érdekeket fogják előtérbe helyezni, hanem a teljes láncét, így a lánctagokkal közösen meghatározott cél elérését fogják priorizálni. Ennek érdekében nem fognak információkat visszatartani önös érdekektől vezérelve, hanem minden a piaccal és a lánctagokkal kapcsolatos releváns információt meg fognak osztani. Véleményem szerint ez az egyik legfontosabb terület, ahol az ostorcsapás-effektus hatásait csökkenteni, és ezáltal az ellátási lánc hatékony működését pedig növelni lehet. Pontosabbak lehetnek a kereslettel kapcsolatos előrejelzések, így közelebb állhatnak a lánctagok rendelési tételnagyságai a valós igényekhez, mely csökkenti a felhalmozott készletek által okozott költségeket, de mégis biztonsággal tudnak reagálni az esetlegesen megnövekedett keresletre.

Az effektus hatásának csökkentése és a koordináció javítása érdekében potenciálisan jó megoldás lehet a különböző szerződéstípusok alkalmazása is a lánctagok között. A témában számos tanulmány készült már, főként a 2000-es és 2010-es évektől kezdődően foglalkoztak a kutatók ezzel a megoldási lehetőséggel. Némely típus kifejezetten a készletek optimális kezelésére ösztönzi a 
lánctagokat [13], más típus fóként az információáramlást javítja a tagok között, illetve döntéstámogató eszközként is funkcionál [11]. Mivel az ostorcsapás-effektus két legfontosabb kiváltó oka az információáramlási hiányosságok, illetve a készletezési problémák, mindkét szerződés segíthet csökkenteni az effektus által okozott negatív hatásokat. További kutatási irányzat lehet ezáltal a különféle szerződéstípusok és az ostorcsapás-effektus kapcsolatának elemzése.

\section{Köszönetnyilvánítás}

A kutatást az EFOP-3.6.2-16-2017-00007 azonosító számú, Az intelligens, fenntartható és inkluzív társadalom fejlesztésének aspektusai: társadalmi, technológiai, innovációs hálózatok a foglalkoztatásban és a digitális gazdaságban című projekt támogatta.

A projekt az Európai Unió támogatásával, az Európai Szociális Alap és Magyarország költségvetése társfinanszírozásában valósul meg.

\section{Irodalomjegyzék}

[1] Arshinder, A., K., Deshmukh, S., G. (2008): Supply chain coordination: Perspectives, empirical studies and research directions, International Journal of Production Economics 115, pp. 316-335.

[2] Ballou, R. H. (1998): Business Logistics Management, 4th edition, Englewood Cliffs: Prentice Hall, N. J., USA

[3] Chen, F., Drezner, Z., Ryan, J. K., Simchi-Levi, D. (200o): Quantifying the bullwhip effect in a simple supply chain: The impact of forecasting, lead times, and information, Management Sciene Vol. 46, No. 3, pp. 436-443

[4] Chikán, A. (1997): Vállalatok és funkciók integrációja, A „Versenyben a világgal” - A magyar gazdaság versenyképességének mikrogazdasági tényezói c. kutatási program Műhelytanulmány sorozata, Z8 kötet

[5] Costantino, F., Di Gravio, G., Shaban, A., Tronci, M. (2013): Exploring the Bullwhip Effect and Inventory Stability in a Seasonal Supply Chain, International Journal of Engineering Business Management 5, 10.5772/56833, online elérhetőség: https://journals.sagepub.com/doi/epub/10.5772/56833 (letöltve: 2020. 01. 08.)

[6] Cooper, M., C., Lambert, D., Pagh, J., D. (1997): Supply Chain Management: More Than a New Name for Logistics, The Internaional Journal of Logistics Management, Vol. 8., Number 1, January, pp. 1-14.

[7] Dobák, M., Antal, Zs. (2010): Vezetés és szervezés - Szervezetek kialakítása és múködtetése, Aula Kiadó Kft., Budapest

[8] Giannoccaro, I., (2018): Centralized vs. decentralized supply chains: The importance of decision maker's cognitive ability and resistance to change, Industrial Marketing Management, available online 3 February 2018 (letöltve: 2020. 01. 06.)

[9] Kaipia, R. (2007): Supply Chain Coordination - Studies on planning and information sharing mechanisms, Helsinki University of Technology Laboratory of Industrial Management Doctoral dissertation series 2007 / 2, Espoo

[10] Malone, T., W., Crowston, K. (1994): The interdisciplinary study of coordination, ACM Computer Surveys, Vol. 26, Issue 1., pp. 87-119.

[11] Molnár, V., Musinszki, Z., Faludi, T. (2018): AHP-Based Decision-Making Model for Supply Chain Coordination by a Modified Revenue-Sharing Contract Type, WSEAS TRANSACTIONS ON BUSINESS AND ECONOMIC 15. : 2018 pp. 273-281.

[12] Pakurár, M. (2012): Az ostorcsapás-effektus teória jelentősége az ellátási lánc menedzsmentben, A Virtuális Intézet Közép-Európa Kutatására közleményei, (4) 5. pp. 235-243.

[13] Sluis, S., De Giovanni, P. (2015): A selection of contracts in supply chains: An empirical analysis, Journal Of Operation Management, Vol. 41, pp. 1-11.

[14] Szegedi Zoltán (2017): Ellátásilánc-menedzsment, Kossuth Kiadó

[15] Tannir, A. (2014): Bullwhip effect variance ratio approximations for aggregated retail orders in supply chains, International Journal of Supply Chain Management, Vol. 3, No. 3, pp. 43-48. 
[16] Zhang, F. (2011): Supply Chain Coordination, book chapter in: Encyclopedia of Operations Research and Management Science, edited by James J. Cochran, internetes elérhetőség: http://apps.olin.wustl.edu/faculty/Zhang/ (letöltve: 2020. 01. 06.) 